\title{
Assessment of designed landscapes and their management practices in selected capital cities in Nigeria
}

\author{
Christiana Olusola Owolabi ${ }^{1 *}$, Oluwole Olawale Ogunsajo ${ }^{1}$, Jacob Goke Bodunde ${ }^{1}$, Olusegun Olufemi Olubode ${ }^{1}$
}

\begin{abstract}
Landscape practices and business engagement have great potentials to uplift city status to either that of developed, under-developed or developing. Among the accruing benefits, are the value added to style of living, improved health status by way of alleviation of stress and development of a buoyant economy through financial in flow from provision of job opportunities and payment to garden owners for relaxation services rendered. A study was conducted to assess the landscape practices potentials and status of selected cities across different geo-political axis of Nigeria. The cities assessed included Abuja, Benin City, Ibadan, Lagos, and Calabar. Assessment was done with the aid of a structured questionnaire that cut across demography, purpose of landscaping, types of landscape materials, and type of maintenance routines. Data collected were analysed using Statistical Package for Social Science (SPSS). Results showed that most people engaged in landscape business had tertiary education, were males and young in age. The specific purposes for the establishment of landscapes for the city ranged from purely aesthetics only, recreation, relaxation centres and business and recreation centres only. Landscape properties which included private/public properties, recreation centres, social parks/gardens, and schools ranged in sizes from small to large hectares. Selected cities at different pedestals in their landscape practices potentials needed awareness campaign for improved development of city potential. In conclusion, thriving landscape business improved the livelihood of the city dwellers through employment opportunities, promotion of private owned businesses and increased the knowledge of landscape practices skills.
\end{abstract}

Keywords: Nigeria, city assessment, landscape practices, landscape management, recreation potentials.

\section{Resumo}

Avaliação de paisagens projetadas e suas práticas de gestão em capitais selecionadas da Nigéria

As práticas paisagísticas e o envolvimento dos negócios têm grande potencial para elevar o status de uma cidade a desenvolvida, subdesenvolvida ou em desenvolvimento. Entre os benefícios, estão o valor agregado ao estilo de vida, a melhoria do estado de saúde por meio da diminuição do estresse e do desenvolvimento de uma economia dinâmica através do fluxo financeiro advindo da oferta de oportunidades de trabalho e pagamento aos proprietários de jardins pelos serviços de relaxamento prestados. Foi realizado um estudo para avaliar o potencial das práticas paisagísticas e o status de cidades selecionadas nos diferentes eixos geopolíticos da Nigéria. As cidades avaliadas incluíram Abuja, Benin City, Ibadan, Lagos e Calabar. A avaliação foi feita com o auxílio de questionário estruturado que abrangeu a demografia, a finalidade do paisagismo, os tipos de materiais e rotinas de manutenção. Os dados coletados foram analisados por meio do Statistical Package for the Social Science (SPSS). Os resultados mostraram que a maioria das pessoas envolvidas em negócios da paisagem tinha educação superior, eram homens e jovens. Os objetivos específicos para o estabelecimento de paisagens para a cidade variavam somente pela estética, recreação, centros de relaxamento e centros comerciais e de lazer. As propriedades paisagísticas que incluíam propriedades privadas/públicas, centros de recreação, parques/jardins e escolas variavam em tamanhos de pequenos a vários hectares. Cidades selecionadas em diferentes graus de potenciais de práticas paisagísticas precisam de uma campanha de conscientização para melhorar o desenvolvimento do potencial da cidade. Concluindo, os prósperos negócios da paisagem melhoraram os meios de subsistência dos moradores da cidade por meio de oportunidades de emprego, promoção de empresas privadas e aumentaram o conhecimento das habilidades nas práticas da paisagem.

Palavras-chave: Nigeria, avaliação da cidade, práticas paisagísticas, manutenção paisagística, potencial de recreação.

\footnotetext{
${ }^{1}$ Federal University of Agriculture, Department of Horticulture, Abeokuta, Nigeria. *Corresponding author: owolabico@funaab.edu.ng, tolusol910@ gmail.com
}

Received Jun 12, 2019| Accepted Mar 06, 2020| Available online Mar 26, 2020

Licensed by CC BY 4.0

https://doi.org/10.1590/2447-536X.v26i1.2055

Area Editor: Alberto Ricordi 


\section{Introduction}

Nigeria is a country situated in the western coastal region of the African continent with a population of over 180 million people. The country is rich in natural beauty like, long blue beaches, rivers and lakes, forests, breath-taking views of the waterfalls and soothing environment. The natural beauty is a main factor behind the up-gradation of Nigeria landscape practices (Lagos live, 2006). The country parades numerous traditional building design concepts and landscape elements at different regions of climatic conditions, socio-economic and cultural background (Ayuba et al., 2019).

The country has experienced paradigm shift in landscape industry starting from the era of Pre- Colonial, Colonial, and Post-Colonial to $21^{\text {st }}$ century. According to Dmochowski (1990), Ayuba (2019), Pre-colonial Nigeria consisted of kingdoms, chiefdoms and city-states; these kingdoms survived and defended themselves based on what the landscape provided: visibility, walls, agriculture, and mining. In pre-colonial Nigeria, cities were designed with spaces, and in Northern Nigeria they functioned as market places, horse riding spheres, areas preserved for durbar usually situated in the front of the emir's palace or other designed areas of the town In western Nigerian, open space served as grounds for festivals, recreation and areas of open market (Oja Oba) while in the eastern part of Nigeria they function as debating grounds (Ilo), point of meetings and wrestling grounds, usually large open areas shaded by Awbu trees with wide spread branches and abundant foliage which adds more RO the scenic value of the ROwn (Dmochowski, 1990).

In the colonial era, the town planning ordinance of 1928 recognized the importance of open space use, after the outbreak of bubonic plague; buffer zones were setup to be used around buildings in the Government Reserved Areas (GRA), to stop the spread of diseases. The recent town planning laws of 1992, backed by decree 88, also encourages the setting aside of open spaces (Dmochowski, 1990; Adeyinka et al., 2006; Ayuba, 2019). In the Post-Colonial and $21^{\text {st }}$ century, studies revealed that (Adedeji, 2006; Atolagbe and Fadamiro, 2006; Ayuba, 2019) colonial influences are responsible for proper landscaping of GRA, public area that are open. The intervention of the "city beautification programmes' carried out by the state governments years back is a built up intervention on landscaping practices idea colonial government established.

As cities develop, both human and vehicular traffic population increase adding to the complexities of industrial emissions and pollutions that coupled with traffic congestions ass $\mathrm{RO}$ various degree of stress the alleviation of stress therefore becomes a paramount target of most landscape projects which individual selection of plants as noise breakers, remediators and hyper accumulator. More recent studies, however, reveal that some of the most notable beautification projects in Lagos involved the conversion of road medians and areas around cloverleaf interchanges RO mini parks (Ogunsote et al., 2011; Ayuba, 2019). These spaces under overhead bridges and other public spaces such as road medians had been taken over by rubbish dumps, squatters, and illegal shanty structures and in some instances, served as open air toilets (Ogunsote et al., 2011; Ayuba, 2019). These spaces have now been converted to car parks and properly landscaped or converted RO mini parks and gardens. Examples include bridges along the Marina, Muriokunla, the Gani Fawehinmi Park, the M.K.O. Abiola Gardens and even the Bar Beach have been beautifully landscaped (Ayuba, 2019). In recent times, the landscape business has become a prominent profession in Nigeria. Landscaping practices serves as a form of trades in Nigeria, by which it sustained many people as source of income generation apart from its traditional function in beatifying the environment. Landscape practice is a service industry, which provides people with fabricated environments where man can live, work, and play, or just passes time (Ingels, 2004; Asiedu et al., 2010). Although, landscaping environment are outdoor, semi-indoor, courtyard and open space. Landscape practices comprises of designing, construction or installation and maintenance. The landscape professional practices have been described by Ingels as a profession with more definitions and descriptions than any other profession. The business of landscape practices combines elements of art and science to create a functional, aesthetically pleasing extension of indoor to outdoor living space with the surrounding (Ingram, 2003; Asiedu, 2010), This can best be carried out by a number of landscape professionals, each of which has a unique role to play (Asiedu, 2010).

Among the many factors, landscaping, an aspect of city development and environmental beautification has gradually gained acceptance and transformed into a culture, although through uncoordinated awareness efforts which with the immense contribution is gradually influencing the national economy at an increasing steady rate. It is not uncommon to see structures either private or public, of different magnitudes developing not without the inclusion of aesthetic plants for purposes of beautification and value addition to such properties. Governmental policies advocating the planting one tree per person has aided as catalyst in the observed transformations. Important ornamental plant production and commercial centres are located in the cosmopolitan city of Lagos in South West Nigeria, alongside other cities in the humid rain forest which include Calabar in South-East and Port-Harcourt in South-South, while other centres characterised by the drier savannah vegetation include Abuja Federal Capital Territory (FCT) and Jos Plateau both located in the Middle Belt zone (Olubode et al., 2015). The cultural diversity and creativity are considered as key assets for human, social and economic development accompanied by the integration of environmental, social and cultural concerns which are woven into the planning, design and implementation of urban development contributing to very positive and encouraging results (UNESCO, 2013). Cities are dynamic organisms. There is not a single 'historic' city in the world that has retained its 'original' character: the concept is a moving target, destined to change with society itself. To preserve the urban historic landscape, strategic and dynamic alli- 
ances need to be built between various actors in the urban scene, foremost between public authorities that manage the city, developers, and entrepreneurs that operate in the city (UNESCO, 2013).

According to Ayuba (2019), there is insufficient data on landscape practices in terms of landscape design or the process of such designs in Nigeria; however, there is adequate data on the historical development of cities and their planning process. Literature is scanty on information regarding city potentials for landscape practices in Nigeria. Although gradually being accepted as a normal day lifestyle, the acceptance of landscape business is still at a low ebb. Nonetheless, the thriving landscape business exist in few capital cities at the different geo-political axes of the country which are limited to only garden ornamental plants and none at the cut flower trade except for decorations at special occasions (Olubode et al., 2015), however their impact levels needed to be assessed. The hypothesis was to determine whether with the myriads of available natural features and monuments the stakeholders in Nigerian Landscape practices and business the relatively abundant work force, supportive environmental factors and knowledge acquisition were able to braze up to flourish landscape practices and business to sustainably upgrade city landscape status and sufficiently perform to maximize the opportunities available in the globally evolving landscape business. Assessment was done to determine the impact of the relative closeness/distance to seaport or seat of government, and the historic influence of the cities on landscape business and practices potential. The objective was to evaluate the present landscape practices and business situation, the impact of landscaping contributions to city developments and the growth of landscape horticulture business in the selected major cities, and the relative potentials welded by each of the selected cities in standard of living of city dwellers.

\section{Materials and method}

Assessment on the landscape status and tourism potentials was conducted on selected Nigerian cities. The cities were selected based on the locations, closeness/distance to port or seat of government and the traditional/historical status. The cities assessed included Abuja, Benin City, Ibadan, Lagos metropolis and Calabar among major cities in Nigeria all at different vegetative belts within the country that range from the Mangrove Rain Forest in Lagos (south west) to Humid Rain Forest in Ibadan (south west), Benin City (south south) and Calabar (south east) with progressive increase in volume of rainfall experienced across the cities, and the Savannah vegetation of Abuja (middle belt zone). (a) Assessments were carried out with the aid of structured questionnaire and each landscape site visited was administered a copy of the questionnaire. A total of 100 questionnaires were distributed in Lagos while 50 each were distributed in Abuja, Benin City, Ibadan and Calabar with respondents that were sampled across the locations. The questionnaire was divided into three sections; Section A covered the socio-economic characteristics of the respondents, which included the gender, age, marital status and educational status. Section B sought for the assessment of the landscape, which covered the purpose of landscaping, type of property, size of the property and types of materials used in the landscape. Section $C$ was about the maintenance aspect of the landscape. Data collected using the demographic, aesthetics and maintenance routines were analysed using descriptive statistical tools and represented in percentages, bar charts and tables. Data were analysed using Statistical Package for Social Science (SPSS).

The first city (a): Abuja Federal Capital Territory (FCT) is the capital city of Nigeria and is located in the centre of the country. It lies between Latitude: $9^{\circ} 03^{\prime} 28^{\prime \prime} \mathrm{N}$, Longitude: $7^{\circ} 29^{\prime} 42^{\prime \prime} \mathrm{E}$, Elevation above sea level: $476 \mathrm{~m}$. Different landscape sites were selected from some districts within the city and these included Garki, Central Area, Wuse, Maitama, Utako, Pape and Apo districts. The second city (b): Benin City is located in the former Mid-West now south-south part of Nigeria and one of the largest cities in the country. It lies between Latitude: $6^{\circ} 20^{\prime} 17^{\prime \prime} \mathrm{N}$ Longitude: $5^{\circ} 37^{\prime} 32^{\prime \prime} \mathrm{E}$, Elevation above sea level: $88 \mathrm{~m}$. It is a flat city at an altitude of about $80 \mathrm{~m}$ above sea level. Sites selected in Benin included Ugbowo, Sapele Road, Kings Road, Egor, Uselu Road, Oba Market, Sakponba Road and others. The third city (c): Calabar is the administrative headquarter of Cross-river state, which had in previous time hosted beauty pageants and was recently recognized nationally for the yearly occurrence of citywide carnivals that served as additional attraction for local visitors and tourists. It lies between Latitude $4^{\circ} 57^{\prime} 32^{\prime \prime} \mathrm{N}$, Longitude $8^{\circ} 19^{\prime} 37^{\prime \prime}$, Elevation above sea level $37 \mathrm{~m}$. Areas visited were Calabar North, Calabar South and Odukpani. The people of the state are known for their warm hospitality. The culture of the people is expressed in various languages, dance, festivals and cuisines. Calabar has rich cultural expression such as masquerades (Ekpo, Nnabo, etc.) traditional dances (Ekombi, Monikim) and cuisines (Ekpang Nkukwo, Edikan Ikong, Afia Efere etc.). The fourth city (d): Ibadan Municipal City, the capital city of Oyo state located in the south west, and the largest city below the Sahara is located in the Southwest part of Nigeria. It lies between Latitude: $7^{\circ} 22^{\prime} 39^{\prime \prime} \mathrm{N}$ Longitude: $3^{\circ} 54^{\prime} 21^{\prime \prime} \mathrm{E}$, Elevation above sea level: $181 \mathrm{~m}$. Sites selected in Ibadan Municipal City were Ido local government, Ibadan South LG, Oluyole L.G, Akinyele L.G and others. The fifty city (e): Lagos the former capital city of Nigeria is located in the Southwest part of Nigeria. It lies between Latitude $6^{\circ} 27^{\prime} 14^{\prime \prime} \mathrm{N}$, Longitude $3^{\circ} 23^{\prime} 40^{\prime \prime} \mathrm{E}$, Elevation above sea level: $11 \mathrm{~m}$. It is the economic and commercial capital of Nigeria. Sites visited in Lagos were Amuwoodofin, Ikeja, Surulere, Lagos Island and Oshodi-Isolo.

\section{Results}

\section{Peculiarities of the cities}

The selected capital cities have peculiarities that distinguish then as either tourism recreation centre or business oriented and otherwise. Lagos and Abuja ranking as respectively being former and current capital cities of $\mathrm{Ni}$ geria exhume the influence of being commercial nerve centers and headquarters of most businesses and government 
headquarters respectively, while Ibadan and Benin City being state capitals for both Oyo and Edo states respectively ranked as low commercial centres while the distant coastal Calabar city has the Obudu cattle ranch ranks solely as Tourism/recreational city. The beach/port distinguishes Lagos for coastal tourism/recreational centres based on the unique resource combination of land and sea offering amenities such as water beaches inclusive of Badagry coconut beach, offering recreational activities such as swimming, fishing, boating, sunbathing and surfing (Obinwanne and Okpoko, 2015). The diversified cultural and historical heritage among the selected cities, notwithstanding the captivating influence of the towering Zuma Rock surrounded by expanse of level plain ground at the entrance to Abuja city showed a developing city with great potentials while both Ibadan and Benin City ranked high among the Nigerian traditional/historical cities endowed with natural features such as hills and valleys although which remained poorly developed. The cities trends towards a peak recreation observed in the Calabar city.
Socio-economic characteristics of the respondents

Socio-economic characteristics of the respondents are presented in Table1. The educational background of Abuja respondents showed that $2.38 \%$ of the respondents had only primary education, $4.76 \%$ had their education up to secondary level while $92.86 \%$ had tertiary education. For the level of education of Benin respondents, the result showed that $6 \%$ of the respondents had primary education, $24 \%$ had secondary education while $68 \%$ had tertiary education. Calabar respondents had $20 \%$ in both secondary and tertiary education. Tertiary education level in Ibadan was 70\% compared to level of secondary education that was $14 \%$. The Lagos respondents had $2 \%$ with primary education, $20 \%$ had secondary education while tertiary education was $67 \%$ of the respondents. A total of 42 landscape sites were visited in Abuja from the 50 questionnaire administered. Table 1 shows that $78.57 \%$ of the respondents were male and $21.43 \%$ were females, $9.52 \%$ were less than 25 years of age, $26.19 \%$ were between ages of 26 and $35,47.62 \%$ were between ages 36 and 45 and $16.67 \%$ were between ages 46 , and 55 above. About $21.43 \%$ of the respondents were single (unmarried) and $78.57 \%$ were married.

Table 1. Socio-economic characteristics of the respondent observed for Abuja metropolis, Benin City, Ibadan City and Lagos City.

\begin{tabular}{|c|c|c|c|c|c|c|c|c|c|c|c|}
\hline \multirow[t]{2}{*}{ Distribution } & & \multicolumn{2}{|c|}{ Abuja } & \multicolumn{2}{|c|}{ Benin City } & \multicolumn{2}{|c|}{ Ibadan City } & \multicolumn{2}{|c|}{ Lagos City } & \multicolumn{2}{|c|}{ Calabar City } \\
\hline & & Percent & Freq & Percent & Freq & Percent & Freq & Percent & Freq & Percent & Freq \\
\hline \multirow{2}{*}{ Gender } & Male & 78.6 & 33.0 & 78.0 & 39.0 & 58.0 & 29.0 & 66.0 & 66.0 & 53.0 & 27.0 \\
\hline & Female & 21.4 & 9.0 & 22.0 & 11.0 & 30.0 & 15.0 & 34.0 & 24.0 & 47.0 & 23.0 \\
\hline \multirow{4}{*}{ Age } & $<25$ & 9.5 & 4.0 & 8.0 & 4.0 & 36.0 & 18.0 & 21.0 & 21.0 & 48.0 & 24.0 \\
\hline & $26-35$ & 26.2 & 11.0 & 32.0 & 16.0 & 40.0 & 20.0 & 25.0 & 25.0 & 40.0 & 20.0 \\
\hline & $36-45$ & 47.6 & 20.0 & 40.0 & 20.0 & 12.0 & 6.0 & 34.0 & 34.0 & 10.0 & 5.0 \\
\hline & $>46-55$ & 16.7 & 7.0 & 20.0 & 10.0 & 12.0 & 6.0 & 14.0 & 14.0 & 12.0 & 6.0 \\
\hline \multirow{2}{*}{ M.Stat. } & Single & 21.4 & 9.0 & 24.0 & 12.0 & 44.0 & 22.0 & 24.0 & 24.0 & 52.0 & 26.0 \\
\hline & Married & 78.6 & 33.0 & 72.0 & 36.0 & 54.0 & 27.0 & 57.0 & 57.0 & 48.0 & 24.0 \\
\hline \multirow{3}{*}{ E. Stat. } & P. Edu. & 2.4 & 1.0 & 6.0 & 3.0 & 4.0 & 2.0 & 2.0 & 2.0 & 0.0 & 0.0 \\
\hline & S.Edu & 4.8 & 2.0 & 24.0 & 12.0 & 14.0 & 7.0 & 20.0 & 20.0 & 20.0 & 20.0 \\
\hline & T.Edu. & 92.9 & 39.0 & 68.0 & 34.0 & 70.0 & 35.0 & 67.0 & 67.0 & 20.0 & 20.0 \\
\hline
\end{tabular}

M. Stat. = Marital Status, E. Stat. = Educational Status, P. Educ. $=$ Primary Education, S. Educ. $=$ Secondary Education, T. Educ. $=$ Tertiary Education

In Benin City, $78 \%$ of the respondents were males while $22 \%$ were females, $8 \%$ were less than 25 years in age, $32 \%$ were between ages of $26-35$ years, and $40 \%$ were between age of 36-45 years while $20 \%$ were between 46 and above. The $24 \%$ of the respondents were single while $72 \%$ were married. In Ibadan, $58 \%$ of the respondents were males while $30 \%$ were females. In $36 \%$ of the respondents,
$48 \%$ were less than 25 years in age, $40 \%$ were between $26-$ 36 years of age and $12 \%$ were between $36-45$ years of age while $12 \%$ were between 46 and above. Lagos city, $66 \%$ of the respondents were male while $34 \%$ were female. Also, $21 \%$ were less than 25 years in age, $25 \%$ were between 26 23 years of age, and 34\% were 36-45 years of age while $14 \%$ were $45-55$ years and above. The $24 \%$ were single 
while $57 \%$ were married. The result for gender analysis across Abuja, Benin, Ibadan and Lagos showed that $79 \%$, $78 \%, 58 \%$ and $66 \%$ of the respondents were males respectively while $21 \%, 22 \%, 30 \%$ and $34 \%$ were females.

Purpose of Landscaping by respondents in selected major cities

The assessment of the purpose of landscaping considered aspects of business \& recreation $(B \& R)$, recreation only (RO), business, aesthetics \& recreation (BA\&R), aesthetics only (AO), aesthetics \& business (A\&B), aesthetics \& recreation (A\&R) and business only (BO) (Figure 1). The responses received for Abuja showed higher frequencies for $\mathrm{A} \& \mathrm{~B}, \mathrm{BO}$ and $\mathrm{AO}(23.31 \%, 19.05 \%$ and $19.05 \%$, respectively) compared RO BA\&R (14.29\%) while lower frequencies were received for $A \& R$ and B\&R $(9.52 \%$ and $9.52 \%$, respectively) and least for RO $(4.76 \%)$ for Benin City the trend of response was AO
(62.0\%) followed by A\&B (20.0\%) compared RO lower frequencies observed for BO, A\&R and B\&R (8.0, 4.0, $2.0 \%$ respectively) while nil was observed for both $\mathrm{RO}$ and BA\&R ( 0.0 and $0.0 \%$, respectively), for Ibadan the trend was AO (60\%) followed by A\&B (28\%), with higher frequencies compared with lower frequencies observed for BO, BA\&R, A\&R and B\&R $(4.0 \%, 3.0 \%, 2.0 \%$, and $2.0 \%$, respectively) while no response was observed for only RO $(0.0 \%)$, for Lagos where similar responses was observed for both $\mathrm{AO}$ and $\mathrm{A} \& \mathrm{~B}(30 \%$ and $30 \%$, respectively) which were higher compared RO lower frequencies observed for BO, A\&R, BA\&Rand, and B\&R (16\%, $15 \%, 12 \%$ and $10 \%$, respectively), while lowest frequency was observed for RO (2.0\%), and the observed responses for Calabar showed higher frequencies for $\mathrm{AO}$ and RO (55.0\% and 45.0\%) with non-occurrence for B\&R, $\mathrm{BA} \& \mathrm{R}, \mathrm{A} \& \mathrm{~B}, \mathrm{~A} \& \mathrm{R}$, and $\mathrm{BO}$ at $0.0,0.0,0.0,0.0,0.0 \%$, respectively (Figure 1).

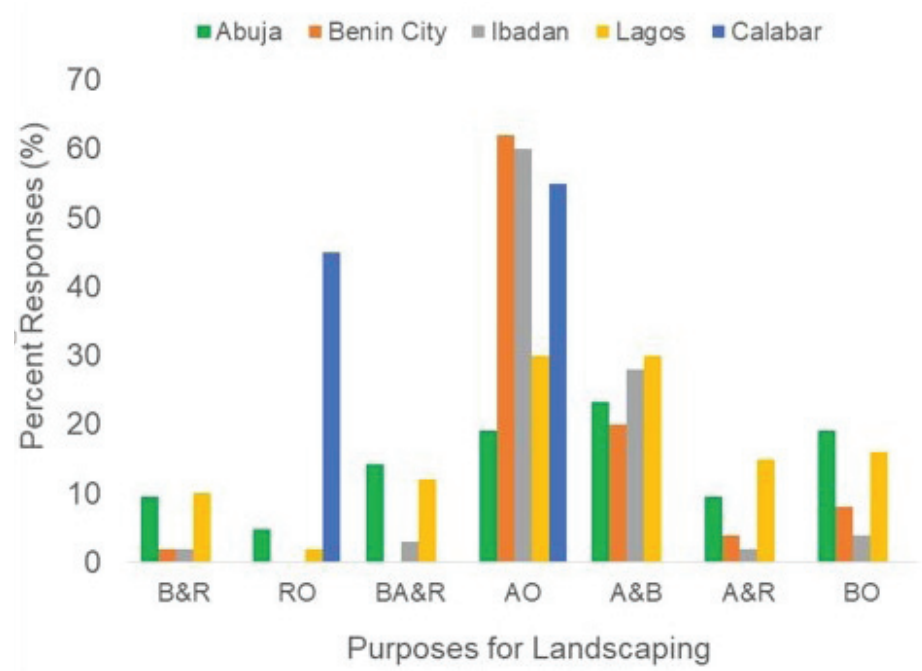

Figure 1. Purpose of landscaping in selected major cities $B \& R=$ Business \& Recreation, $\mathrm{RO}=$ Recreation only, BA\&R = Business, Aesthetics \& Recreation, AO = Aesthetics only, $\mathrm{A} \& \mathrm{~B}=$ Aesthetics \& Business, $\mathrm{A} \& \mathrm{R}=$ Aesthetics \& Recreation, $\mathrm{BO}=$ Business only.

Nonetheless the responses observed in the assessment made for purpose of landscaping from respondents showed that for the business \& recreation had higher frequencies for Lagos and Abuja $(10>9.52 \%$ respectively $)$ compared to Benin City and Ibadan $(2.0>2.0 \%$ respectively), for RO both Abuja and Lagos $(4.76>2.0 \%)$ had higher frequencies compared RO nil occurrence observe for both Benin City and Ibadan $(0.0>0.0 \%)$, for business, aesthetics \& recreation both Abuja and Lagos (14.29 > 12\% respectively) had higher frequencies compared RO Ibadan and Benin City (3.0 $>0.0 \%$ respectively), for aesthetics only, responses for Benin City, Ibadan and Lagos (62\%, 60\% and 30\%, respectively) were higher compared RO Abuja (19.05\%), for aesthetics \& business, responses for Lagos, Ibadan, Abuja and Benin City had similar occurrences with the frequencies of $30 \%, 28 \%, 23.32 \%$ and $20 \%$ respectively but nil for Calabar, for aesthetics \& recreation, responses for
Lagos and Abuja (15>9.52\%, respectively) were higher compared RO Benin City and Ibadan $(4.0 \%$ and $2.0 \%$ respectively) but nil for Calabar for business only, responses for both Abuja and Lagos (19.05\% and 16\%, respectively) were higher compared to Benin City and Ibadan $(8.0 \%$ and $4.0 \%$, respectively) but nil for Calabar. Among these observations only Calabar ranked high in RO only but had nil for mixed recreation, while other cities had varying degrees of lower responses for RO but non-occurrence $(0.0 \%) \mathrm{ob}-$ served for both Ibadan and Benin City, and for mixed RO which included Business, Aesthetics \& Recreation only Benin City had non-occurrence (0.0\%) (Figure 1).

Types of landscape elements by respondents in selected major cities

The cities were assessed for the types of landscape materials used which included soft landscape only (SL), hard 
landscape only (HL) or combination of soft and hard landscapes (S\&HL) (Figure 2). The responses observed for soft landscape only showed that both Calabar and Abuja (55.0\% and $45.24 \%$ ) had higher frequencies followed by Ibadan (26\%) compared RO lesser occurrences observed for both Lagos (11.8\%) and Benin City (6.0\%). For hard landscape only, the trend of results showed Calabar $(45.0 \%)$ with high- er occurrences followed by Benin City (16\%) compared RO almost none in Lagos $(1,0 \%)$, and nil for Abuja and Ibadan $(0.0 \%$ and $0.0 \%)$. For combination of soft and hard landscape, the trend results showed Benin City, Ibadan and Lagos (78\%, 74\% and 74\%, respectively) had higher frequencies compared RO least frequency for Abuja (54.76\%) and least occurrence observed for Calabar (25.0\%) (Figure 2).

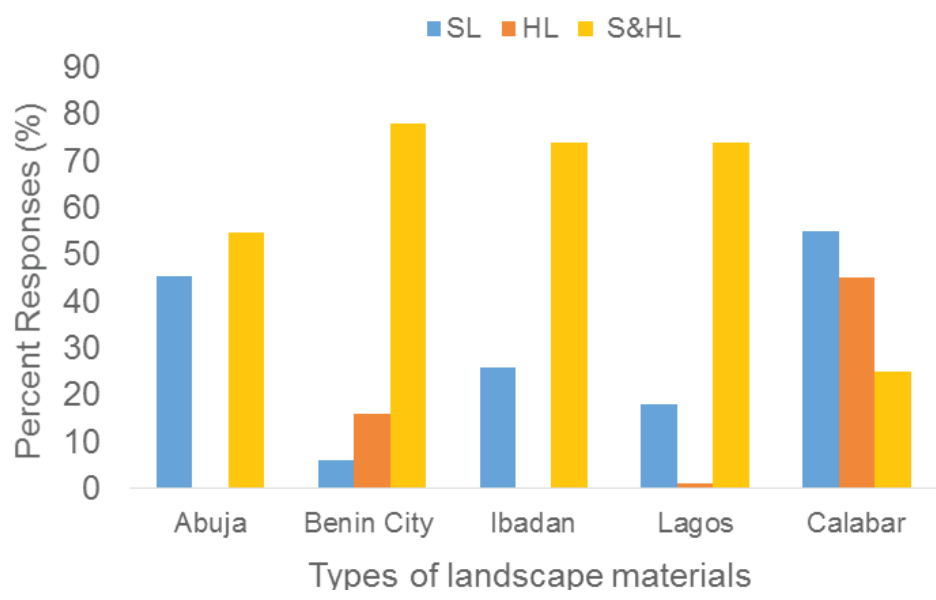

Figure 2. Assessment for types of landscape elements prevailing in selected cities. SL $=$ Soft Landscape, HL = Hard Landscape, S\&HL = Soft \& Hard Landscape

Nonetheless the types of landscape materials used for Abuja showed moderate occurrences of both S\&HL and SL (54.76\% and $45.24 \%$, respectively) compared to nonexistence of HL $(0.0 \%)$, for Benin City responses showed high occurrence of S\&HL (78\%) compared to very low occurrence of the HL (16\%) followed by lower responses for SL $(6.0 \%)$, for Ibadan responses were in the order of S\&HL (74\%) higher compared to very low occurrence of SL $(26 \%)$ and the none existence of HL $(0.0 \%)$, and for Lagos responses showed high occurrence of S\&HL (74\%) followed by the lower responses for SL (18\%) compared to very low occurrence to almost none existence of HL $(1.0 \%)$, while a difference approach was observed for Calabar which had moderate occurrences of both SL 55.0 and HL (55.05\% and $45.0 \%$, respectively) followed by the nose diving response with lower occurrence of S\&HL (25.0\%) which was opposite to the general prevailing responses for the use of S\&HL as observed for other cities ( Figure 2).

\section{The quality of maintenance tools and equipment}

The cities were assessed for the quality of maintenance tools and equipment used which described the level of affluence and type/level of patronage enjoyed by respondents (Figure 3). The equipment identified in common use were categorized as sophisticated grade equipment which included riding mower, sprinkler, and hedge trimmer, the $\mathrm{mid} /$ medium grade equipment included bush cutter and pruning shear, while simple grade equipment include the use of cutlass, secateurs and hoe. The responses received from Abuja gave a blend usage of the mid/medium, simple and sophisticated in that order at $38.10 \%, 35.71 \%$ and
$26.19 \%$, respectively, for Benin City had more of simple grade equipment followed by sophisticated and $\mathrm{mid} / \mathrm{me}$ dium grade equipment in that order at $75 \%, 10.2 \%$ and $6.1 \%$, respectively. Ibadan had more of simple grade equipment followed by $\mathrm{mid} /$ medium and sophisticated grade equipment in that order at $58 \%, 33 \%$ and $9.5 \%$, respectively, while Lagos had more of mid/medium grade equipment followed by simple and sophisticated grade equipment in that order at $60 \%, 28 \%$ and $12.9 \%$, respectively. In the use of sophisticated grade equipment, the trend was Abuja, Lagos, Benin and Ibadan in that order. In the $\mathrm{mid} /$ medium grade equipment, the trend was Lagos, Abuja, Ibadan and Benin in that order. The Calabar city was not assessed.

In the simple grade equipment, the trend was Benin, Ibadan, Abuja and Lagos in that order (Figure 3). The responses to type of maintenance tools and equipment used for sophisticated grade equipment showed high patronage from respondents in Abuja (26.19\%) followed by lower patronage from Lagos. Benin City and Ibadan in that order with frequencies of $12.9,10.2 \%$ and $9.5 \%$, respectively. $\mathrm{Mid} /$ medium grade equipment responses showed very high patronage from respondents in Lagos (60\%) compared to lower patronage from respondents in Abuja and Ibadan with frequencies of $38.1 \%$ and $33.0 \%$, respectively and Benin City (6.1\%), for simple grade equipment showed the very high frequency in Benin City $(75 \%)$ followed by the moderate patronage from respondents in Ibadan (58\%) compared to fewer and lower patronage from respondents in Abuja and Lagos with frequencies of $35.71 \%$ and $28.0 \%$ respectively (Figure 3 ). 


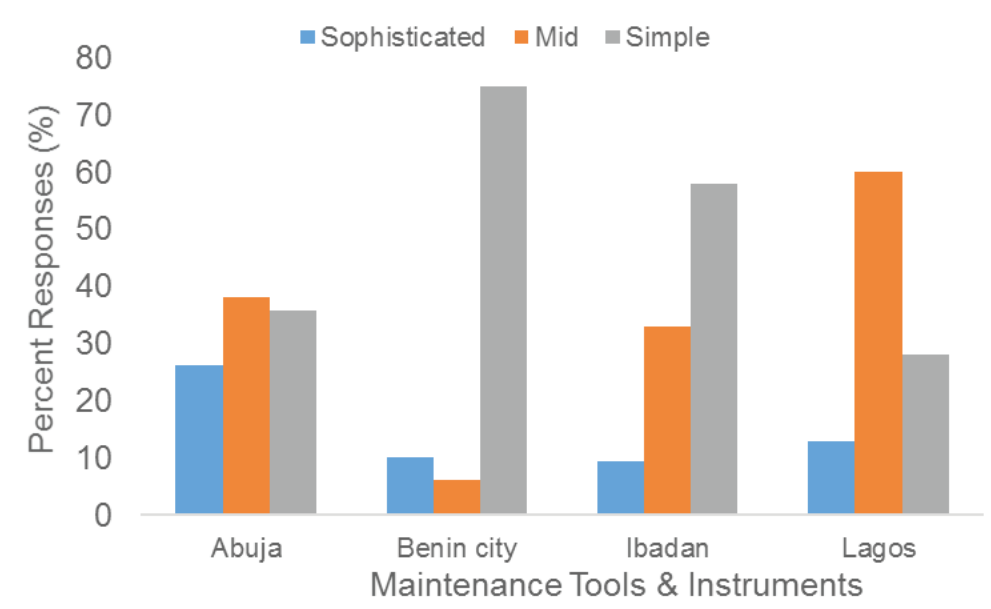

Figure 3. Assessment for type of maintenance tools and equipment used in selected cities.

\section{Level of maintenance routine observed in selected cities}

The cities were assessed for level of maintenance routine, which described the nature of activities carried out in the cities (Figure 4). The responses received for Abuja showed that the trend of observation was weekly (7-daily) (42.38\%) and daily (1-daily) (26.19\%) were more frequent than both operation carried out fortnightly (14-daily) and three-days interval (3-daily) (15.5\% and $9.52 \%$, respectively) compared to monthly (30-daily) $(0.0 \%)$ that was non-existent. Benin City trend of observation was 7-daily and 1-daily (38\% and 34\% respectively) which were more frequent than 30-daily (15\%) while least frequencies was observed for both 14 -daily and 3 daily $(2.5 \%$ and $0.5 \%$, respectively). Nonetheless there was a twist observed for Ibadan where 30 daily (55\%) had highest frequency compared to other intervals of 1-daily, 7-daily and 14-dailym (11\%, 10\% and 10\%, respectively) while the least frequency was observed with 3-daily $(0.7 \%)$. Lagos trend of observation showed 3-daily (45\%) with higher frequency compared to lower frequencies from 1-daily, 14-daily and 7-daily at the frequencies of $15 \%, 12.7 \%$ and $9.62 \%$ respectively com- pared to least occurrence for 30-daily (5\%). Lastly for Calabar the trend of observation for both 30-daily and 1-daily (40\% and 30\%) had highest frequencies followed by 7-daily $(20 \%)$ which was more frequent than 14-daily (10\%) while 3 -daily $(0.0 \%)$ was non-existent (Figure 4$)$. Nonetheless the responses for maintenance routine at the 1-daily interval had the for the cities a trend of Benin $>$ Abuja $>$ Lagos $>$ Ibadan with frequencies of $34 \%, 26.19 \%, 15 \%$ and $11 \%$, respectively, for the 3-daily intervals was Lagos and Abuja (45\% and $9.52 \%$, respectively) compared to Ibadan and Benin with $0.7 \%$ and $0.5 \%$, respectively, for the 7-daily interval, higher frequency was observed for Abuja and Benin (42.38\% and $38 \%$, respectively) compared to lower frequencies observed for Ibadan and Lagos with $10 \%$ and $9.62 \%$, respectively, for the 14-daily interval, the response was at higher frequency for both Benin and Abuja (20.5\% and 15.5\%, respectively) compared to Lagos and Ibadan with $12.7 \%$ and $10 \%$, respectively, while lastly for the 30-daily interval, very high was observed for Ibadan (55\%,) compared to Benin (15\%) which was also higher compared to very low frequency for Lagos $(5 \%)$ and the nil existence for Abuja (0.0\%) (Figure 4).

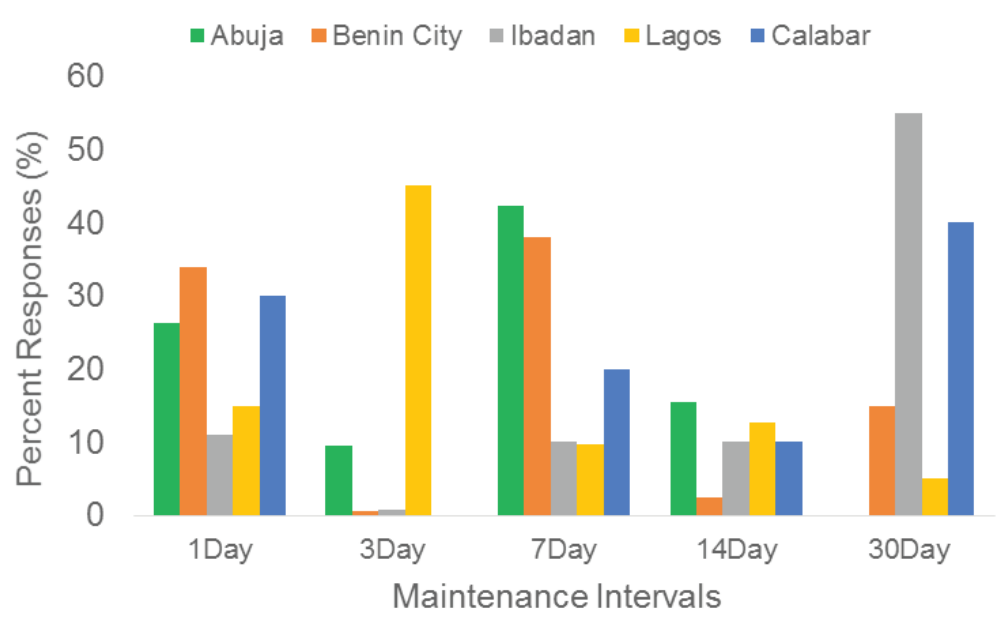

Figure 4. Assessment for level of maintenance routine in selected cities. 
In Abuja and Benin, maintenance routine were mostly done on weekly bases, in Ibadan city, the routine of operations were usually carried out monthly while in Lagos, operations were done at 3-daily intervals (Figure 4). However, majority of the cities were landscaped for aesthetics purposes to lift up the standard of the cities and to make the cities attractive for visitors/tourists. Most places landscaped were mostly public places owned by governments, which included institutions, conference centres, parks and amusement centres. The sizes of landscaped area were between 1 ha-10 ha of land space in most of the cities.

\section{Size of properties landscaped}

The assessment for the size of properties included small hectarage ( $<1 \mathrm{ha})(\mathrm{SH})$, medium hectarage (1-4 ha) $(\mathrm{MH})$, large hectarage (5-10 ha) (LH) and very large hectarage ( $>$ 10 ha) (VLH) (Figure 5). The responses received showed moderate frequencies for properties with small hectarage with a trend of both Benin city followed by Ibadan $(38 \%$ and $26 \%$, respectively) having more of smaller properties than Lagos (11\%) which had more than Abuja (2.38\%). The properties with medium hectarage had a trend of Abuja (52.38\%) at higher frequencies higher compared to higher frequencies for Ibadan, Lagos, Benin City in that order (42\%, 40\% and 38\%, respectively). Although slightly lower compared to properties with medium hectarage, the properties with large hectarage with a trend of Lagos, Abuja and Ibadan (49\%, 42.86\% and 30\%, respectively) occurred at higher frequencies compared to observed in Benin City $(18 \%)$, while lastly properties with very large hectarage occurred less frequently where the trend showed Benin city (6\%) having better frequency compared to Abuja, Ibadan and Lagos at the least frequencies of $2.38 \%, 2.0 \%$ and $1.0 \%$, respectively (Figure 5).

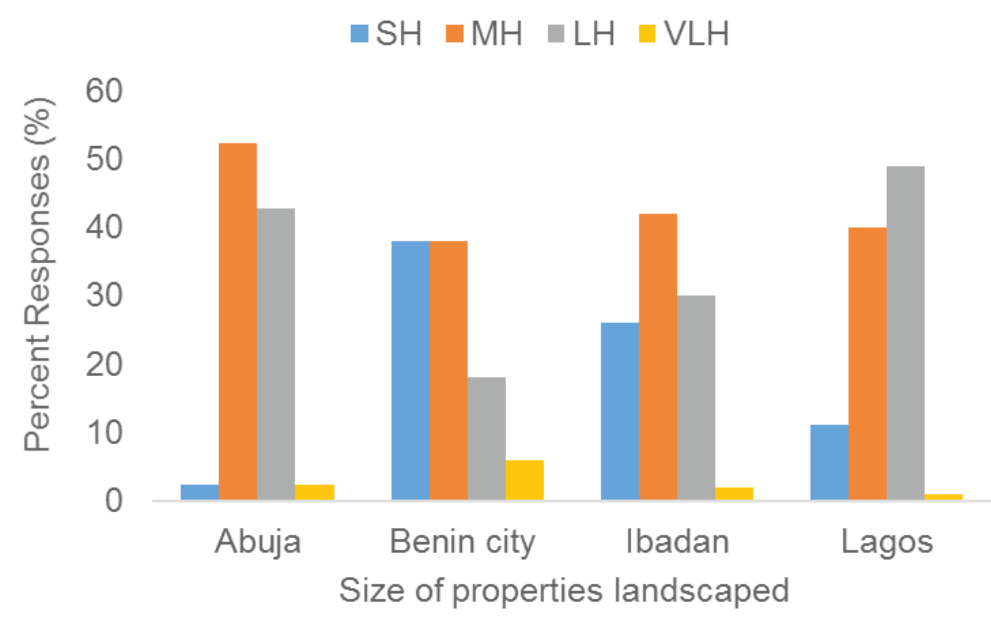

Figure 5. Assessment for size of properties landscaped in selected cities $\mathrm{SH}=$ small hectarage, $\mathrm{MH}=$ medium hectarage, $\mathrm{LH}=$ large hectarage, $\mathrm{VLH}=$ very large hectarage.

Nonetheless size of properties at Abuja showed a trend of medium and large hectarage $(52.38 \%$ and $42.86 \%$, respectively) occurring at higher frequencies compared to those with small and very large hectarage $(2.38 \%$ and $2.38 \%$, respectively). The size of properties in Benin City showed a trend of small and medium hectarage (38\% and $38 \%$, respectively) at higher frequencies compared to those with large hectarage (18\%), while properties with very large hectare occurred at lesser frequency $(6.0 \%)$. The size of properties in Ibadan at higher frequencies showed a trend of medium, large hectarage and small hectarage in that order $(42 \%, 30 \%$ and $26 \%$, respectively) higher compared to least occurrence of very large hectarage $(2.0 \%)$. The size of properties in Lagos showed a trend of large hectarage and medium hectarage ( $49 \%$ and $40 \%$, respectively) with higher frequencies compared to small hectarage $(11 \%)$ and the least occurrence of very large hectarage at 1.0\% (Figure 5).

\section{Type of landscape ownership}

The type landscape ownership assessed properties as either belonging to private or public ownership (Figure $6)$. The responses received for type of landscape ownership showed that private ownership expected with residents with higher level of affluent had more frequent occurrence in Abuja and Calabar (60\% and 55\%, respectively) at close to double rate of occurrence compared to observed lower occurrence in Lagos (37\%), which was double compared to least occurrences in Benin and Ibadan at frequencies of $20 \%$ and $18 \%$ respectively, while for public ownership that belonged to government or business/industries had most occurrence in Ibadan and Benin (82\% and 80\%, respectively) followed by lesser occurrence in Lagos (63\%) and least occurrence in Abuja (40\%) which was about half compared to observed in Ibadan and Benin and two-third compared as observed in Lagos (Figure 6). Nonetheless Abuja FCT had 
higher occurrence of private ownership (60\%) compared to lower occurrence for government or business/industry (40\%), Benin and Ibadan had lower occurrence of government or business/industry ( $20 \%$ and $18 \%$, respectively) compared to more occurrence of private ownership properties ( $80 \%$ and $82 \%$, respectively), while Lagos had lower occurrence of private ownership (37\%) compared to government or business/industry (63\%) (Figure 6).

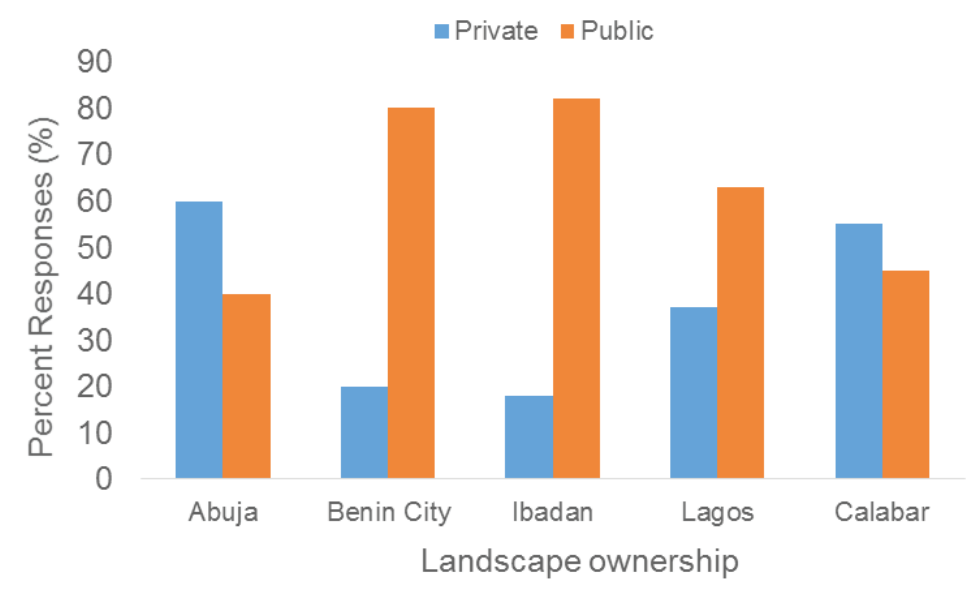

Figure 6. Assessment for type of landscape ownership in selected cities.

Types of properties landscaped in selected major cities

The cities were assessed for the types of properties landscaped which included conference centre (CC), recreation centre (RC), hotels (HT), social parks \& garden (SP\&G), schools (SC) (Figure 7). The responses to the types of properties landscaped showed that for Abuja FCT, the SP\&G (74.45\%) had most frequent occurrence compared to RC and HT (9.76\% and $9.45 \%$, respectively) while similar but least occurrences was observed for both CC and SC (4.76\% and $4.76 \%$ ), for Benin City, both the CC and RC (47\% and $39 \%$, respectively) had more than double occurrences compared to SP\&G (18.7) while least occurrences were observed for both HT and SC (2.5\% and $2.5 \%$, respectively), for Ibadan, both the CC and RC (44\% and 38\%, respectively) had many times more occurrences compared to SP\&G (10.4\%) while least occurrences were observed for both HT and SC (5.5\% and 5.5\%, respectively), for Lagos, both the SC and CC (46.2\% and 38\%, respectively) had more than double occurrences observed compared to both RC and HT ( $15 \%$ and $10.5 \%$, respectively) while the least occurrence was observed for SP\&G (5.5\%), lastly for Calabar, the RC $(58.0 \%)$ at about double occurrence compared to SP\&G $(30.0 \%)$ which had also more than double occurrences compared RO CC (12.0\%) while least occurrences with HT $(4.0 \%)$ and the non-occurrence for SC $(0.0 \%)$ were observed (Figure 7).

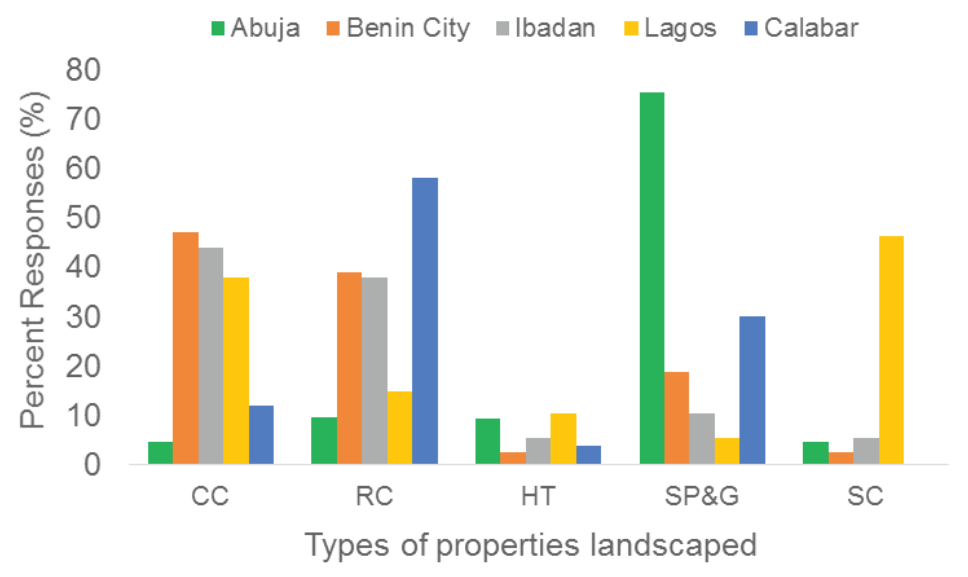

Figure 7. Assessment for types of properties landscaped in selected major cities.

$\mathrm{CC}=$ Conference centres, $\mathrm{RC}=$ Recreation centres, $\mathrm{HT}=$ Hotels, $\mathrm{SP} \& \mathrm{G}=$ Social Parks 7 Gardens, $\mathrm{SC}=\mathrm{Schools}$. 
Nonetheless the responses to the types of properties landscaped showed that for CC, responses for Benin City, Ibadan and Lagos in that order $(47 \%, 44 \%$ and $38 \%$, respectively) had more occurrences compared to Calabar $(12.0 \%)$ and Abuja (4.76)\%, for RC the trend of observation was Calabar (58\%) followed by both Benin City and Ibadan (39\% and 38\% respectively) had more occurrences compared RO Lagos (15\%) while least occurrence was observed with Abuja (9.76\%), for HT, the trend for both Lagos and Abuja (10.5\% and 9.45\%, respectively) were more compared to Ibadan and Calabar $(5.5 \%$ and $4.0 \%$ respectively) while least occurrence was observed for Benin City $(2.5 \%)$, for SP\&G, the response for Abuja $(75.45 \%)$ at more double occurrence compared to Calabar (30.0\%) had more frequent occurrences compared to Benin City and Ibadan (18.7\% and $10.4 \%$, respectively) while least occurrence was observed for Lagos (5.5\%), lastly for SC, the trend of observation showed that Lagos $(46.2 \%$, ) had most frequent occurrence compared to both Ibadan and Abuja (5.5\% and $4.76 \%$, respectively) while the least occurrence was observed with Benin City (2.5\%) but non-occurrence was observed for Calabar (0.0\%) (Figure 7).

\section{Discussion}

Van Der Borg and Russo (2005) had earlier reported that culture counts for cities as the powerhouses of the contemporary society whereby culture is observed as a full-fledged economic sector that - as any other generates impacts on the urban environment, ranging from direct and indirect expenditure to employment generation there are different levels of practices and professional training within the industry. Some aspects of the practices does not require formal University education, however others do (Asiedu, 2010). As observed in this study, the majority of people involved in landscape practices and business had formal education which indicated that landscape practice was a major employment opportunity for job seekers and could be a major economic force in the future.

This is in agreement with the report of Fagbayide and Jonusa (2006) that formal education enhanced appreciation and subsequently management of landscape work and that landscape practice is an elitist profession, levels of landscaping such as landscape construction, management and planning and architecture/design require formal education and training and a licence to operate in most countries (Ingels, 2004; Asiedu, 2010). This Landscaping is highly appreciated or done by people (and users/Clients) with formal education based on their knowledge of plants and their importance in the living environment of man which has a definite root in human needs for nature around him. The gender sensitive and unmarried age brackets involved in the business indicated that more male were involved in the profession which could be due RO the energy and time demanding nature of the most operations carried out in landscape work. Most ladies compared to the men were therefore observed as more involved with nursery activities than direct landscape field operations.
The types of landscape materials used described the general and specific appearances of the cities. The contrasting weather conditions of Abuja and Calabar had a meeting point in the economic pressures forcing a different approach on the residents in both cities. Like the high hotel costs, building costs and rents in urban areas and costs for transportation put economic pressure on the residents. The types of landscape materials used by respondents in the choice of cheaper the sole use of soft landscaping showed that Calabar, Abuja and Ibadan cities had economic pressures forcing the sole use of soft landscaping indicating the prevailing high cost of materials and relative poor purchasing powers respectively. The sole use of hard landscaping with less maintenance cost compared to the sole use of soft landscaping in both Calabar followed by Benin City which appears as unconventional was premeditated by the existence of high torrential rainfall at the location in order to prevent hazards of floods and soil erosion that dominated the South South to South East Geo-political areas of Nigeria. This indicated the influence of economic pressures and environmental conditions influencing the choice of landscape materials used. Hence the choice of the hardy and costly hardscapes and high skill demand for construction of slabs, concrete and interlocking blocks for paving much than the use of lawn/grasses in the landscape.

The high prevalent use of combined soft and hard landscape materials observed for Benin City, Ibadan and Lagos indicated the high sense of professional skills prevailing in the cities, although economic considerations such as high cost of living versus high service charges might have incapacitated professional practice in Abuja Federal Capital City and Calabar. Both Abuja that harbours the headquarters of most business ventures and the nation Federal Government ministries offices/parastatals and Calabar that is situated close to oil exploration regions experienced economic considerations such as high cost of living versus high service charges compared both Benin City and Ibadan with low clients affordability occasioned by the lower service charges and lower cost of living followed by Lagos with low clients affordability in the high cost of living that had respite from the lower service charges.

One of the major factors in landscape maintenance is equipment at the disposal of the maintenance crew and that of maintenance equipment observed as mostly used (Fagbayide and Jonusa, 2006). In the relative term, some cities are more developed than others are and could attract inflow of more economic benefits than others could. In the general terms, developing countries are faced with low income and high population growth. Thus, development entails a modern infrastructure (both institutional and physical) most importantly diverting from agriculture (Godfrey and Clarke, 2000). The development of a country is measured with statistical indexes such as income per capita (per person) (gross domestic product), life expectancy, the rate of literacy (ignoring reading addiction), et cetera. As indicated by the UN Human Development Index (HDI), a compound indicator of these statistics, to gauge the level of human development for countries where data is available. (Godfrey 
and Clarke, 2000), developing countries are therefore those that have not achieved a significant degree of industrialization relative to their populations, and have, in most cases, a medium to low standard of living. More so, there is a strong association between low income and high population growth (Eruotor, 2014).

However in the present study, it was observed that the farther away from port, beach city or important commercial centers the poorer the approach in the use of modern equipment and hence in the choice of equipment. Thus maintenance tool employed for landscape practice had dictates from the per capita income of the residents and thereby described the level of affluence and affordability for the available services. This was confirmed by the maintenance routine observed Abuja and Benin City the occurrence of more of the working class participating in landscape business and operating at weekly intervals more frequently for Abuja than Benin City probably as weekend business (at double rate compared to the two weekly intervals) and vice versa at lesser occurrence for the more available non-working class operating as full time participants at daily interval. Some of the residents with white collar jobs working in government offices could neither afford nor engage the use of highly sophisticated working tools unlike residents in the private sector that have thriving businesses. Hence, each category would employ services that are regarded as fit or affordable based on the relative per capita income. Abuja and Lagos cities made use of medium grade equipment more often than either the simple or sophisticated grade equipment which would means that the equipment used in maintaining the landscape are moderately advanced, while in Benin City and Ibadan the equipment and tools were low grade simple tools. The dominance in the use of sophisticated grade equipment showed the Abuja city had more of patronage from high-class people compared to very low patronage in other cities.

For the mid/medium grade equipment, showed that Lagos had highest patronage from middle class compared to moderate response from Abuja which had more of businesses by virtue of being the nation's capital city and Ibadan for closeness to a high class city like the former capital city Lagos, compared to low response from Benin City observed to be in the hunter land and far from these cities with high influence. This was confirmed by the maintenance routine observed for Lagos which indicated a more occurrence as full time participants for the 3-daily intervals and the lesser occurrence of the full time participants in the daily (1-daily) intervals and the least occurrence of the working class working on part time basis at both two weekly followed by one weekly interval. For simple grade equipment, the traditional and historical cities of Benin City followed by almost similar response from Ibadan had more patronage of low class people with lesser purchasing power which more than double the responses from either of Abuja or Lagos respectively.

The maintenance routine observed for Ibadan indicated more of working class operating more frequently at monthly intervals and the equal and lesser occurrence of the nonworking and working class categories operating at daily, weekly and two weekly in that order. Thus, the Federal
Government parastatals dominated Abuja that had all social classes in almost equal mix compared to business city of Lagos that had more of middle class, while State Government parastatals dominated traditional and historical cities of Benin City and Ibadan had more patronage from low class categories of the social mix. This is in agreement with UNESCO that urban heritage areas generate much higher returns than areas devoid of any cultural historic 43 significance, and that proximity to excellent monuments and sites usually draws high-end service-sector businesses and residents, who are willing to pay more for locations with prestige and status, which is reflected in land and property values (UNESCO, 2013). Thus both Benin city followed by Calabar by virtue of the higher occurrence of daily activities would appear more neatly kept compared to both Abuja and Lagos while Ibadan would appear more poorly kept.

The maintenance routine observed in Abuja, Lagos, Benin and Calabar indicated that the respondents keep more than one job making them to participate in landscape business only at the weekends and fortnightly. The conference/ recreation centre approach dominated types of properties landscaped in the cities mostly observed for Benin City and Ibadan in that order followed by Lagos but least occurrence was observed for Abuja compared to other types of properties. According to Bankole (2002), the ownership of recreation centres visited was highly skewed in favour of governments, with the Federal, State, and Local Government accounting for about $13 \%, 32 \%$, and $13 \%$, respectively. The assessment report further indicated that the purpose of visit was mainly sightseeing, accounting for $45 \%$ of household demand for tourism followed by visit for leisure (Bankole, 2002). Overall, the indication was that domestic demand for recreation was low. Moreover, the distribution of tourist destinations suggested that Nigerian households visited festivals and zoos more than any other destination (Bankole, 2002). Nonetheless Hotel business dominated the types of properties landscaped mostly observed for Lagos and Abuja in that order both regarded as cities with high cost of living with lesser occurrences for Ibadan regarded as one of the cities with least cost of living in Nigeria and Calabar with peculiar nature as the most accommodating city and least occurrence observed for Benin City.

According to Christie et al., (2013), the high hotel costs are primarily due to high hotel development costs and the cost of debt financing. Thus in Nigeria, hotel construction costs are upwards of US\$400,000 per room for a midmarket hotel; in Ghana the cost is US\$250,000 per room. Median hotel development costs elsewhere in the world are US $\$ 200,000$ per room for a full-service hotel (Christie et al., 2013). Social parks and garden business dominated the types of properties landscaped mostly observed for Abuja followed by lesser occurrences observed for Benin City and Ibadan probably due to low patronage from residents. The least occurrence observed for Lagos has to due with the compact nature of the city with least area of available land space compared to other cities like Ibadan the largest city south of Sahara. School business dominated the types of properties landscaped mostly observed for Lagos compared to low occurrences in other cities and the non-occurrence in Calabar. 
The more occurrence of small hectarage sized properties in form of recreation with conference centres accommodating bigger crowd of people dominated Benin City and Ibadan, which were more of government owned properties, the recreation in social parks and gardens accommodating lesser crowd of people dominated Abuja indicating the different approaches to life styles in these cities. The more frequent occurrence of large hectarage sized properties observed in Lagos, Abuja and Ibadan in that order but of different ownerships in form of schools, social parks, gardens, and conference/recreation centres respectively showed the high space requirement of these businesses and the types of focuses of property owners in these cities. The school business in the Benin City, Ibadan and Abuja were mostly of government owned schools compared to privately own of school business in Lagos. Moreover, the schools in Lagos had futuristic approach by investment in landscaped environment for the younger citizens, while the recreation/conference centres in Benin City and Ibadan and the recreation in social parks in Abuja all in the current focus targeted mainly the adult citizens. The government or business/industry projects, which used less of, landscape features and lesser of costly amenities compared to private ownership that would include amenities such as fountains, cascades and swimming pools, while most amenities common with government or business/industry only included streetlights and pedestrian bridges. The traditional/historical cities of Benin City and Ibadan thus depended more on the government or business/industry projects composed mostly of the rigid and formal requests compared to the freestyle, state of the art, and high-class taste that dominated the private ownership.

Distinguished the city as one of the frontline recreation centres in Nigeria, the non-occurrence of business related activities in Calabar as observed in the study showed that business either in form of hoteling or commerce was non-existent not even alongside the recreation, indicating that the city should be refocused from the lack of drive for entrepreneurship to maximize the inflow of foreign exchange into tourism/recreation. The peculiarity of Calabar was such that recreation and aesthetics in any form were not mixed indicated that landscaping for tourism might have different approaches than required for aesthetics alone. It is envisaged that with time this trend in Calabar will change. According to Taylor (1973) cited by Bankole (2002), tourist/recreation trade provides the opportunity to develop local folk art such as straw baskets, hats, wooden carvings, ornaments, and trinkets and helps raise the standard of living of producing areas (Bankole, 2002). In contrast to Calabar, the Abuja residents landscaped mainly for business and aesthetics only wherein more of the residents did landscaping as an aspect of creating a serene and welcoming environment for the business, which indicated that Abuja accommodated more of relaxation in business than actual tourism. The lower responses for tourism described these other cities as not recreation oriented more so as traditional historical cities most natural features especially in Benin City were yet to be developed for recreation.
Nonetheless, from the ecological point of view tourism/ recreation services are often more acceptable and preferable than any other industrial production, as it is environmentally friendlier (Eruotor, 2014). The problem is that it is not easy to change the traditional way of life of the local communities, as this often creates pseudo conflicts. Undoubtedly, in some regions or countries the alternative industries are even more harmful to the environment than recreation which has the power to affect cultural change. Successful development of a resource can lead to numerous negative impacts. Among these are overdevelopment, assimilation, conflict, and artificial re-construction. While presenting a culture to tourists may help preserve the culture, it can also dilute or even destroy it. The point is to promote tourism/recreation in the region so that it would both give incomes and create respect for the local tradition and culture (URS, 2007).

However, the Nigerian traditional/historical cities of Ibadan and Benin City were not able to key into this reality of the UNESCO report. Although tourism/recreational activity also involves economic costs, including the direct costs incurred by recreation businesses, government costs for infrastructure to better serve tourists, as well as congestion and related costs borne by individuals in the community. This study therefore identified that Lagos despite being a port and beach city the lower responses for recreation described the city as not keying into the benefits of tourism as most of the existing natural features were yet to be developed for recreation/tourism. The lack of one or two of these factors might have been responsible for the poor development of recreation centres. Nonetheless, economic benefits and costs of tourism reach virtually everyone in the region in one way or another. Economic impact analyses provide tangible estimates of these economic inter dependencies and a better understanding of the role and importance of tourism in a region's economy (Kolb, 2006.).

\section{Conclusions}

There is a general recognition of landscape business as a useful tool for enhancing property value, but imbibing the workable idea to transform the existing local environment through the introduction of landscape features for the establishment of relaxation centres either for personal or for business is still at low ebb, hence the idea of recreation seems far out of reach in these locations except in the south east like Calabar. The landscape business improved the livelihood of the city dwellers through employment opportunities, promoting recreation and provision of serene environment. In the hypothesis the available natural features and monuments due to neglect could not contribute sufficiently to upgrade the cities recreation status, nonetheless the cities were ranked in their recreation potentials and except for Calabar City that had sole recreation, other cities had more of relaxation business and mixed tourism. There is need therefore to explore the naturally existing physiographic features of each of the cities for their recreation/ tourism potentials. Except for the southeast city of Calabar, already benefitting from the trade of recreation, 
all the selected cities although at different pedestals in their recreation potentials needed awareness campaign for the development of the cities potentials through the various levels of infrastructural and capital investment from government and private sector involvements in the realization of the noble idea.

\section{Author Contribution}

C.O.O. ${ }^{0000-0002-8415-321 x}$ : analysed the data collected for the research, implementation, evaluation and writing of the article edit the manuscript. O.O.O. ${ }^{0000-0002-9644-011 x}$ : carried out the project in Abuja Nigeria as part of the fulfilment of the requirements for the Degree of Bachelor of Agriculture. G.J.B.: was the major supervisor for research. O.O.O. ${ }^{0000-0003-2077-8322}$ : Assisted in the preparation of the study and correction of the manuscript.

\section{Acknowledgements}

We acknowledge the effort and support of Miss Omene Ejirhoghene Catherine, Mr. Koyejo Ronald Olatoye and Mr. Whutu Samon Akpojotor in administered the questionnaires in all the selected Cities.

\section{References}

ASIEDU, J.B.K.; BUAH, J.N.; BLANKSON, J.E. The landscape industry and practice in Ghana. Proceedings of the International Horticultural Congress on Science and Horticulture for People on Advances in Ornamentals Landscape and Urban Horticulture, v. XXVIII, p.1023-1032, 2010.

AYUBA, P.; KOLO, S.; AYUBA, E.E.; SHUAIBU, S.I. Cultural landscape design in Nigeria during the pre-colonial, colonial and twenty-first century. Civil and Environmental Research, v.11, n.2, p.69-74, 2019.

BANKOLE, A. The Nigerian tourism sector: economic contribution, constraints, and opportunities. Journal of Hospitality Financial Management, v.10, n.1, p.71-89, 2002.

CHRISTIE, I.; FERNANDES, E.; MESSERLI, H.; TWINING-WARD, L. Tourism in Africa: harnessing tourism for growth and improved livelihoods. 2013. Available at: <https://www.worldbank.org/content/dam/Worldbank/ document/Africa/Report/africa-ourism-report-2013-keymessages.pdf. Accessed on: March 5 ${ }^{\text {th }}, 2020$.

ERUOTOR, V. The economic importance of tourism in developing countries: case study of Lagos, Nigeria. 2014. Available at: <https://core.ac.uk/download/pdf/38104881. pdf $>$. Accessed on: March 5 ${ }^{\text {th }}, 2020$.
FAGBAYIDE, J.A.; JONUSA, J.E. Perception of landscape maintenance in Nigeria: a case of study of Ibadan. Proceedings of the $24^{\text {th }}$ Annual Conference of the Horticultural Society of Nigeria, v.24, p.202-204, 2006.

GODFREY, K.; CLARKE, J. Tourism development Handbook. London: Continuum Ltd., 2000. 232p.

KHUOJE, N. Africa's Tourism set to boost economic growth. 2013. Available at: <http://www.thisdaylive.com/ articles/africa $>$. Accessed on: March 5 th 2020.

KOLB, B.M. Tourism marketing for cities and towns. Oxford: Elsivier Limited. 2006. 328p.

LAGOS LIVE. Your online guide to the capital of West Africa. 2006. Available at: <http://www.lagoslive.com/ beaches $>$. Accessed on: November, 2013.

OBINWANNE, C.O; OKPOKO, P.U. Comparative assessment of coastal tourism potentials of selected areas in Rivers State, Nigeria. International Journal of Scientific \& Technology Research, v.4, n.12, p.262-269, 2015.

OLUBODE, O.O., ADEKOLA, S.U., IDOWU, S.M. Evaluation of flowering pattern, yield and yield determinants of hybrid tea rose in response to seasonal variations and applied organic manure rates. American Journal of Plant Sciences, v.6, n.464-482, 2015.

TAYLOR, F. The tourist industry in Jamaica, 1919-1939. Social and Economic Studies, v.22, n.2, p.205-227, 1973.

TUNDE, A.M. Harnessing tourism potentials for sustainable development: a case of Owu water falls in Nigerians. Journal of Sustainable Development in Africa, v.14, n.1, p.119-133, 2012.

UNESCO. Recommendation on the Historic Urban Landscape, UNESCO, Paris. 2011. Available at: <http:// portal.unesco.org/en/ev.php $>$. Accessed on: November, 2013.

UNESCO. Landscape planning: The basis of sustainable landscape development. 2013. Available at: <whc.unesco. org/document/123570>. Accessed on: November, 2013.

URS. Assessing the value of coast to Victoria. The Victorian Coastal Council Department of Sustainability and Environment, East Melbourne. 2007. Available at: <www. vcc.vic.gov.au/publications/AssessingtheValueoftheCoast to Victoria.pdf>. Accessed on: November, 2013.

VAN DER BORG, J.; RUSSO, A.P. The impacts of culture on the economic development of cities. European Institute for Comparative Urban Research (EURICUR). Rotterdam: Erasmus 19 University, 2005. 395p. 
WORLD TOURISM ORGANIZATION. Affiliate Members Regional Reports, Volume four-Tourism in Africa: A rool for development. UNWRO: Madrid, 2015. p.110.

WTTC - World Travel and Tourism Council. Travel \& Tourism Economic Impact 2013 Sub Saharan Africa”. WTTC: London, 2013.
WTTC. Tourism Economic Research 2010, World Travel and Tourism Council, London. 2010. Available at: <www. wttc.orgHall/eng/Tourism_Research/Economic_Research/>. Accessed on: November, 2013. 